\title{
Hardal Gazına Maruz Kalmış Kimyasal Yaralıların Tıbbi Yönetiminin Retrospektif Değerlendirilmesi ve Öneriler
}

\author{
Retrospective Evaluation of Medical Management of Chemical \\ Casualties Who were Exposed to Sulfur Mustard and \\ Recommendations
}

Sermet Sezigen, Levent Kenar

Sağlık Bilimleri Üniversitesi, Gülhane Sağlık Bilimleri Enstitüsü, Tıbbi KBRN Ana Bilim Dalı, Ankara, Türkiye

\begin{abstract}
Özet: Sülfür mustard (hardal gazı) yakıcı harp maddeleri grubunda yer alan kimyasal bir silahtır. Bu kimyasal silah; güçlü bir yakıcı ajan olmasının yanı sıra sitostatik, mutajenik ve sitotoksik etkilere sahiptir. Bu çalışmanın amacı; kimyasal bir saldırı sonucu hardal gazına maruz kalan dört yaralının belirti ve bulgularını, detaylı klinik seyirlerini, uygulanan tedavi yaklaşımlarını incelemek ve hardal gazı maruziyetinde uygulanan tıbbi yönetime ilişkin tecrübeleri paylaşmaktır. 09 Mart 2016 tarihinde Irak'nn Kerkük şehri yakınlarında bulunan Tuzhurmatu kasabasına kimyasal bir saldırı düzenlenmiştir. Bu saldırı sonucu ortama yayılan hardal gazına maruz kalan dört yaralı; olaydan 15 gün sonra Ankara'daki bir devlet hastanesinde tedavi altına alınmıștır. Hastaların yapılan detaylı fizik muayenelerinde çift taraflı konjunktivit, gözlerde yanma, fotofobi, genizde yanma ve ağrı, yutma güçlüğü, burun akıntısı ve balgamlı öksürük tespit edilmiştir. Hastaların yapılan cilt muayenelerinde özellikle üst ve alt ekstremiteler başta olmak üzere tüm vücut yüzeylerinde birinci/ikinci derece yanık sekelleri ile hipo ve hiperpigmente alanlar izlenmiştir. Maruziyetten sonraki 15. günde dört hastadan elde edilen detaylı fizik muayene bulguları ve tipik maruziyet hikayeleri kapsamında, söz konusu hastaların Irak'ta düzenlenen kimyasal terörist saldırıda hardal gazına maruz kaldıkları değerlendirilmiștir. Bu hastaların tıbbi yönetiminde semptomatik bir tedavi yaklaşımı uygulanmıştır. Kimyasal yaralıların tıbbi yönetiminde bilgi, kritik altyapı, planlama ve personel anlamında hazırlıklı olmak her sağlık tesisi için mutlak bir zorunluluktur.
\end{abstract}

Anahtar Kelimeler: sülfür mustard, hardal gazı, kimyasal terörizm, kimyasal yaralı, dekontaminasyon, KBRN

Abstract: Sulfur mustard (mustard gas) is a vesicant chemical warfare agent. Besides it's vesicant properties, mustard gas has also cytostatic, mutagenic, and cytotoxic effects. The aim of this study was to investigate signs and symptoms, detailed clinical picture, treatment modalities in four casualty who were exposed to mustard gas and to share experience on medical management of victims who were exposed to mustard gas. A chemical terrorist attack which was organized by non-state actors hit Tazahurmatu, a district of Kerkuk, Iraq on March 09, 2016. Four patient who were exposed to mustard gas during the terrorist attack were hospitalized in Turkey at the 15th day after the exposure. Bilateral conjunctivitis, soreness, photophobia, sore throat, dysphagia, rhinorrhea, and productive coughing were noted during the detailed physical examination of four patient. Additionally, both first and second-degree burn scars and hypo/hyperpigmented areas were observed in the whole-body surfaces of four patients, especially in the upper and lower extremities. In consideration of detailed medical examinations of four patient at 15th day after the exposure and typical medical histories of the exposure, it was concluded that four patients were exposed to mustard gas during the chemical terrorist attack in Iraq. Symptomatic treatment approach was performed for the medical management of these patients. Prepardness of health facilities in mean knowledge, critical infrastructure, planning, and personnel is essential for the medical management of chemical casualties.

Keywords: sulfur mustard, mustard gas, chemical terrorism, chemical casualty, decontamination, CBRN

ORCID ID of the authors: S.S. 0000-0002-4658-5046; L.K. 0000-0002-6613-1308 


\section{Giriş}

Kimyasal silahlar; insanları, hayvanları ve bitkileri fonksiyonlarını bozarak etkisiz hale getirmek veya öldürmek için kullanılan toksik kimyasal maddelerdir (1). Sülfür mustard [bis(2-kloroetil) sülfit] yakıcı harp maddeleri grubunda yer alan kimyasal bir silahtır. İlk kez 1822 y1lında Fransiz kimyager Despretz tarafindan sentez edilmiștir. 1886 yılında Alman kimyager Victor Meyer sülfür mustardı kimyasal bir silah olabilecek yüksek saflıkta sentez etmeyi başarmıştır (2). Sülfür mustard kimyasal bir saldırıda ilk kez Birinci Dünya Savaşında kullanılmışıtır. Bu savaşta neden olduğu çok sayıda zayiat nedeniyle "Savaş Gazlarının Kralı" olarak anılan sülfür mustardın, hardalı anımsatan keskin kokusundan dolayı diğer bir ismi ise "Hardal Gazı"dır (3).

HG güçlü bir yakıcı ajan olmasının yanı sıra sitostatik, mutajenik ve sitotoksiktir. HG vücutta özellikle gözlerden, solunum sisteminden ve ciltten absorbe olarak öncelikle bu sistemlerde etkilerini gösterir (4) Düşük buharlaşma ve düşük çözünme özelliklerinden dolayı HG sıcaklık, yağmur, rüzgâr gibi dış ortam şartlarına dayanıklı bir yapıda olup, kullanıldığı açık alanlarda herhangi bir bozunuma uğramadan uzun süre kalabilir. Cilde temas eden HG'nın \%80'i buharlaşırken \%20'si ciltten absorbe olur. Ciltten absorbe olan kismın \%60'1 ciltte kalırken, \%40'1 ise sistemik dolaşıma geçerek etkisini gösterir (5) HG dolaşıma geçtikten sonra episülfonyum iyonu oluşturarak sülfidril, imidazol, amino ve karboksilat grubu gibi pek çok biyomolekül ile birlikte özellikle DNA zincirlerinde guanin nükleotidini alkilleyerek hücre ölümüne ve çeşitli kanserlerin gelişimine neden olur $(6,7)$

HG'na maruz kalındığında çoğunlukla keskin bir sarımsak kokusu dışında herhangi bir belirti hissedilmez. HG'na temas sonucunda ağrı meydana gelmez. Maruziyetin en dikkat çekici yönü; sonrasında saatler boyunca herhangi bir belirti veya bulgunun görülmediği "latent" dönemdir. Belirti ve bulguların ortaya çıkış süresi; maruz kalınan toplam doza, toplam maruziyet süresine ve maruziyet esnasinda kimyasal koruyucu donanımın kullanılıp kullanılmamasına bağlı olarak değişkenlik gösterebilir (8) HG'na maruz kalınması sonrasinda ilk belirtiler gözlerde batma hissi, göz yaşarması, gözde kızarıklık, burun ve genizde ağrı veya yanma hissidir (9)

Yakın geçmişte HG'na kaza sonucu maruz kalan hastalara ilişkin yapılan sınırlı sayıda yayin mevcuttur $(8,10) 2013$ yılında başlayan Suriye İç savaşında, özellikle Suriye'nin kuzeyinde devlet dışı aktörler tarafından $\mathrm{HG}$ yoğun şekilde kullanılmıştır. HG'nın kullanıldığı kimyasal terörist saldırılardan etkilenen kurbanlara ilişkin tanı ve tedavi süreçleri ile elde edilen dersler tarafimızdan yayımlanmıştır $(11,12)$

$\mathrm{Bu}$ vaka-kohort çalışmamızda kimyasal bir saldırı sonucu hardal gazına maruz kalan dört yaralının belirti ve bulgularını, detaylı klinik seyirlerini, uygulanan tedavi yaklaşımlarını incelemeyi ve hardal gazı maruziyetinde uygulanan tıbbi yönetime ilişkin tecrübelerimizi paylaşmayı amaçladık.

\section{Hardal gazı maruziyetinin tıbbi öyküsü}

09 Mart 2016 tarihinde saat 16:00 civarında Irak'in Kerkük şehri yakınlarında bulunan ve ağırlıklı olarak Türkmenlerin yaşadığ 1 Tuzhurmatu kasabasına devlet dişı aktörler tarafindan roket ve havan mermilerinin kullanıldığı kimyasal bir saldırı düzenlenmiştir. Saldırı sonucunda ikisi çocuk olmak üzere dört kişi hayatını kaybetmiş, dört binden fazla sivil yaralanmıştır (13) Görgü tanıkları; söz konusu saldırı esnasında yere düşen roket ve havan mermilerinin herhangi bir şiddetli bir patlama, parlama veya basınç yaratmaksızın sadece koyu renkli yoğun bir duman çıkardıklarını ve aynı anda havada kesif bir sarımsak kokusunun da hissedildiğini ifade etmişlerdir.

Söz konusu kimyasal saldırıdan etkilenen dört hastanın yaş, cinsiyet ve maruziyet kaynağına uzaklıklarına ilişkin bilgiler Tablo 1'de sunulmuştur. Birinci ve ikinci hasta; söz konusu kimyasal saldırı sonrasında sığındıkları alandan çıktıklarında patlamamış bir roketin toprağa saplandığ1 görmüşlerdir. 
Etraftaki sivillere zarar vermemesi için söz konusu mühimmatı elleri ile kazarak topraktan çıkartmış ve güvenlik görevlilerine teslim etmişlerdir. Muhtemelen HG ile dolu olan mühimmata çıplak elle dokunarak HG'na doğrudan temas etmişlerdir. Üçüncü ve dördüncü hasta; bahçelerine düşen bir mühimmattan açığa çıkan sarımsak kokulu koyu renkli dumanın içinde kalmıştır.

Maruziyetten sonraki ilk bir saat içerisinde tüm hastalarda gözler, nazofarinks/orofarinks ile solunum sisteminde ortaya çıan belirti ve bulgular Tablo 2'de özetlenmiştir. Aynı akşam dört hasta; saldırı sırasında üzerlerinde olan kıyafetleri değiştirmiş ve banyo yapmışlardır. Maruziyet sonrasında 6. saatten itibaren ortaya çıkan cilt belirtileri (kaşıntı ve eritem) nedeniyle Tuzhurmatu'da bulunan sağlık ocağına başvuran dört hasta, ayn1 durumda bulunan çok sayıda yaralı ile Kerkük'teki bir hastaneye tanı ve tedavi amacıyla sevk edilmiştir. Özellikle cilt lezyonlarının dağılımı ve ciddiyeti sebebiyle dört hasta; kimyasal saldırıdan sonraki 15. günde benzer şikâyetleri olan 34 hasta ile toplu olarak Ankara'daki bir devlet hastanesine havadan tahliye edilmiștir. Hastalar ilgili devlet hastanesinde ayn klinikte tedavi altına alınmıştır (13).

Tablo 1.Hardal gazına maruz kalan dört hastaya ait demografik bilgiler

\begin{tabular}{|c|c|c|c|}
\hline & Yaş & Cinsiyet & Maruziyet kaynağına olan uzaklığı (metre) \\
\hline 1. Hasta & 18 & Erkek & Doğrudan temas \\
\hline 2. Hasta & 24 & Erkek & Doğrudan temas \\
\hline 3. Hasta & 29 & Kadın & $5-10$ \\
\hline 4. Hasta & 37 & Erkek & $5-10$ \\
\hline
\end{tabular}

Tablo 2.Hardal gazı maruziyetinden sonra belirti ve bulguların ortaya çıkış süreleri

\begin{tabular}{lc}
\hline \multicolumn{1}{c}{ Belirti ve Bulgular } & $\begin{array}{c}\text { Maruziyet Sonrasi Ortaya } \\
\text { Çıkış Süresi }\end{array}$ \\
\hline Gözler & $1-10$ dakika \\
\hline $\begin{array}{l}\text { Gözlerde batma/yanma, kaşıntı, kızarıklık, göz yaşarması } \\
\text { Nazofarinks/Orofarinks }\end{array}$ & $10-60$ dakika \\
\hline Burun akıntıSı, burunda yanma, genizde yanma/ağrı, ses kısıklığı & $10-60$ dakika \\
Solunum Yolu & \\
\hline Kuru öksürük ve solunum sılkıntısı & $6-8$ saat \\
Cilt & $6-24$ saat \\
\hline Kaşıntı & $24-48$ saat \\
\hline Kı̈arıklık & \\
\hline
\end{tabular}

\section{Bulgular}

HG maruziyetinden 15 gün sonra dört hastanın ülkemizde gerçekleștirilen ilk fizik muayenelerinde; alınan detaylı tıbbi öykü yanında tespit edilen göz, solunum sistemi ve cilt bulguları kapsamında, söz konusu hastalara uluslararası hastalık sinıflandırma sistemi "ICD-10"a göre "kimyasallar ve zararlı maddelere maruz kalma ve kazayla zehirlenme (X-49)" tanısı konulmuştur.

Hastaların yapılan göz muayenelerinde; çift taraflı konjunktivit, gözlerde yanma ve ağrı ile fotofobi tespit edilmiştir. İlave olarak ikinci hastada blefarit tespit edilmiştir. Hastaların göz bulguları Tablo 3'te sunulmuştur.

Hastaların yapılan nazofarinks, orofarinks ve solunum sistemi muayenelerinde; hepsinde genizde yanma ve ağrı, yutma güçlüğü, burun akıntısı ve balgamlı öksürük tespit edilmiştir. Dinlemekle tüm hastaların akciğerlerinde kaba raller duyulmuştur. Hastaların ilgili sistemlerine ilişkin bulgular Tablo 4'te sunulmuştur. 
Hastaların yapılan cilt muayenelerinde özellikle üst ve alt ekstremiteler başta olmak üzere tüm vücut yüzeylerinde birinci/ikinci derece yanık sekelleri ile hipo ve hiperpigmente alanlar izlenmiştir. Hastaların cilt bulguları Tablo-5'te ve cilt lezyonlarının izlendiği anatomik bölgeler Şekil-1'de sunulmuştur. Hastalar özellikle ilk günden beri devam eden inatçı bir kaşıntı tarif etmiştir.

Hastalarda göz lezyonlarının tedavisi için suni göz yaşı ve antibiyotikli göz damlası (moksifloksasin), solunum sistemi lezyonlarının tedavisi için nemlendirilmiş $\% 100$ oksijen inhalasyonu, parenteral steroid (metilprednisolon) inhale glukokortikosteroid (budesonid) ve bronkodilatatör (ipratropium bromür/salbutamol) kullanılmıştır. Cilt lezyonlarının tedavisinde antiseptikler (nitrofurazon), antibiyotikli preperatlar (rifamisin, basitrasin/neomisin) ve antiseptik kremler (gümüş sülfadiazin) tercih edilmiştir. Hastalara her gün düzenli olarak yanık pansumanı ve debritmanı uygulanmış ve profilaksi amaciyla kısa süreli antibiyoterapi (sefazolin, moksifloksasin) planlanmıştır. Hastaların bulantı şikâyetlerinin tedavisinde antiemetikler (metoklopramid, dimenhidrinat) kullanılmıştır. Hastalarda maruziyetin başından beri devam eden kaşıntı için sistemik antihistaminik (fenireamin maleat) uygulanmıştır. Ağrı yönetimi için parasetamol, deksketoprofen ve tramadol tercih edilmiştir.

Tablo 3. Hardal gazı maruziyetinden sonraki 15. günde göz bulguları

\begin{tabular}{lccccc}
\hline & $\begin{array}{c}\text { Bilateral } \\
\text { konjunktivit }\end{array}$ & $\begin{array}{c}\text { Gözde } \\
\text { yanma/ağrı }\end{array}$ & $\begin{array}{c}\text { Göz kapağında } \\
\text { ödem }\end{array}$ & $\begin{array}{c}\text { Göz } \\
\text { yaşarması }\end{array}$ & Fotofobi \\
\hline 1. Hasta & + & + & - & - & + \\
2. Hasta & + & + & + & - & + \\
3. Hasta & + & + & - & - & + \\
4. Hasta & + & + & - & - & + \\
\hline
\end{tabular}

Tablo 4. Hardal gazı maruziyetinden sonraki 15. günde nazofarinks, orofarinks ve solunum sistemi bulguları

\begin{tabular}{|c|c|c|c|c|c|c|}
\hline & $\begin{array}{c}\text { Genizde } \\
\text { yanma/ağrı }\end{array}$ & $\begin{array}{l}\text { Orofarinks } \\
\text { ödemi }\end{array}$ & $\begin{array}{c}\text { Burun } \\
\text { akıntısı }\end{array}$ & Disfagi & Öksürük & Balgam \\
\hline 1. Hasta & + & - & + & + & + & + \\
\hline 2. Hasta & + & - & + & + & + & + \\
\hline 3. Hasta & + & - & + & + & + & + \\
\hline 4. Hasta & + & - & + & + & + & + \\
\hline
\end{tabular}

Tablo 5. Hardal gazı maruziyetinden sonraki 15. günde cilt bulguları

\begin{tabular}{|c|c|c|c|c|c|}
\hline & Kaşıntı & Eritem & Bül & Hipo/hiperpigmentasyon & Yanık yüzey alanı \\
\hline 1. Hasta & + & - & - & + & $\% 15-20$ \\
\hline 2. Hasta & + & - & - & + & $\% 15-20$ \\
\hline 3. Hasta & + & - & - & + & $\% 35$ \\
\hline 4. Hasta & + & - & - & + & $\% 15-20$ \\
\hline
\end{tabular}




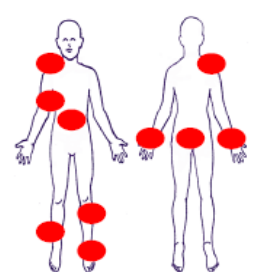

1. Hasta (Erkek, 18 yaş)

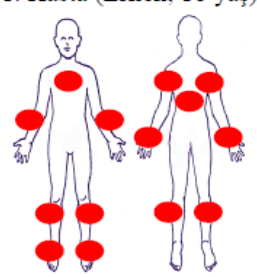

3. Hasta (Kadın, 29 yaş)

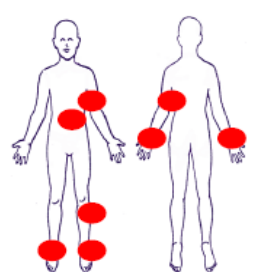

2. Hasta (Erkek, 24 yaş)

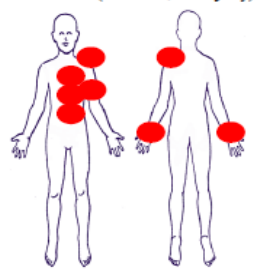

4. Hasta (Erkek, 37 yaş)

Şekil 1. Hardal gazına maruz kalan dört hastada cilt lezyonlarının dağılımı (Maruziyetten sonraki 15. gün)

\section{Tartışma ve Sonuç}

HG maruziyeti sonrasında; mümkün olan en kısa süre içerisinde $\mathrm{HG}^{\prime}$ dan etkilenen kişinin olay bölgesinden uzaklaşması/uzaklaştırılıması, tüm elbiselerini çıkartarak hızla kişisel dekontaminasyon (arındırma) işlemini yapması önemlidir çünkü lipofilik bir kimyasal olan HG dakikalar içerisinde ciltten emilir (6). Kişisel dekontaminasyon için elbiseler çıkartıldıktan sonra imkân varsa profesyonel dekontaminasyon kitleri kullanılmalıdır. $\mathrm{Bu}$ kitlerin mevcut olmadığ 1 durumlarda ise dekontaminasyon maksadiyla tüm vücudun sabunlu su ile yikanması ve sonrasinda bol su ile durulanması önerilir. Özellikle koltukaltı ve perine bölgesinde detaylı bir temizleme yapılması uygundur. Gözler mümkünse serum fizyolojik ile temizlenmelidir. $\mathrm{Bu}$ imkan bulunmadığı takdirde gözler bol su ile yıkanmalıdır (14).

HG'na maruz kalan dört hasta, olaydan sonra sadece ellerini ve yüzlerini yıkamışlar, HG bulaşmış kıyafetleri içerisinde akşama kadar zaman geçirmişlerdir. Bu nedenlerden dolayı dört hastada özellikle cilt lezyonlarının daha yaygın ve ciddi seyrettiği değerlendirilmiştir.

HG'na maruz kalan kişiler; olay yerinde veya olay yerinden hastaneye tahliye esnasinda dekontaminasyona tabi tutulmamış iseler, acil servise kabul edilmelerinden önce bu kişilere detaylı bir tıbi dekontaminasyon uygulanmas1 mutlak zorunluluktur. Dekontaminasyon işlemini gerçekleştirecek sağlık personelinin tam yüz maskesi, kimyasal filtre, kimyasal koruyucu tulum, kauçuk eldivenler ve kauçuk botlar ile teçhiz edilmesi gerekir (9):- Dekontaminasyon öncesinde hastanın tüm kıyafetleri çıkartılır ve çift kat olarak tıbbi atık torbasina konulur. Torbalar etiketlenir ve güvenli bir bölgede biriktirilir. Dekontaminasyon işlemi sonrasında söz konusu atık torbaları kolluk kuvvetlerine teslim edilir. Dekontaminasyon siv1 sabun ve su kullanılarak, 1slat-yıka-durula prensibine uygun olarak gerçekleştirilir (9)

Maruziyetten sonraki 15. günde dört hastanın göz, solunum sistemi ve ciltlerinde tespit edilen bulgular ile tarif ettikleri maruziyet hikayelerinin, daha önceki çalışmalarda yayımlanmış ve HG'na maruz kaldıkları tespit edilen hastaların fizik muayene bulguları ve maruziyet hikayeleri ile büyük ölçüde benzerlik gösterdiği değerlendirilmiştir (11, 12).

Gözler; diğer sistemlere göre HG'na daha duyarlıdır. Düşük dozlarda bile $\mathrm{HG}$ maruziyeti gözleri etkiler (6). Temas sonrasinda gözlerde batma ve yanma hissi ortaya çıkar, takiben her iki gözde kızarıklık meydana gelir (10). Bu tabloyu göz 
kapaklarında ödem gelişimi, ağrılı göz kapağı hareketlerinin neden olduğu blefarospazm ve fotofobi takip eder (12). Maruziyetten 15 gün sonra yapılan fizik muayenede; dört hastada çift taraflı konjunktivit, gözlerde yanma, göz diplerinde ağr ve fotofobi tespit edildi. Sadece ikinci hastada, sayılan bulgulara ilave olarak göz kapaklarında ödem izlendi. Hastalarda geçici veya kalıcı körlüğe neden olabilecek herhangi bir patoloji saptanmadi. Semptomatik tedavinin yanı sıra gözde kuruluk ve 1şığa hassasiyet şikayetleri nedeniyle hastalara suni gözyaşı reçete edildi ve dıș mekânlara çıkıldığında koyu renkli güneş gözlüğü kullanımı tavsiye edildi.

HG inhalasyonu özellikle üst solunum yolunu etkiler (6). Solunum sisteminde semptomların ortaya çıkış süresi; solunan gazın havadaki konsantrasyonuna, kurbanın dakikadaki solunum hızına ve toplam solunum süresine bağlı olarak değișiklik gösterir. HG’nın solunmas1 nazofarinks ve orofarinks mukozasını etkileyerek burun akıntısına, genizde yanma hissine ve kuru öksürüğe neden olur. Yüksek dozda HG maruziyeti sonrasında ses telleri etkilenir ve ses kısıklığ meydana gelir. HG'nın alt solunum yollarına kadar etkili olduğu durumlarda, solunum yollarını döşeyen mukozada ödem, nekroz ve bazen psödomembran oluşumu izlenebilir (5). Trakeobronşiyal hasar meydana geldiği takdirde maruziyetten yaklaşık 48 sonra trakeobronșit veya bronkopnömoni gelișebilir (4). Maruziyetten 15 gün sonra yapılan fizik muayenede; hastalarda genizde yanma hissi ve burun akıntısının devam ettiği, kuru öksürügün yerini balgamlı bir öksürüğe bıraktığ 1 tespit edildi. Hastalarda ses kısıklığ 1 izlenmedi. Semptomlara yönelik olarak düzenlenen tedavi kapsamında nemlendirilmiş $\% 100$ oksijen inhalasyonu, parenteral steroid, inhale glukokortikosteroid ve inhale bronkodilatatörler kullanıldı. Uygulanan tedavilerinin tüm hastalarda solunum sistemine ilişkin şikâyetleri azalttığı tespit edildi.

HG maruziyetinin en tipik belirti ve bulguları ciltte izlenen eritem ve sonrasında gelişen büllerdir. Cilt bulguları buhar veya sıvıya doğrudan temas sonrasında ortaya çıkar. Alınan doza bağlı olarak, 2 ila 48 saat sonra epidermiste yaygın eritemler ortaya çıkar. $\mathrm{Bu}$ klinik görünüme inatçı kaşıntı eşlik eder (5). Ciltte eritem ile ödem birlikte görülebilir. Sonrasında hiperemik bölgelerde, aynı anda veya farklı zamanlarda çok sayıda vezikül ortaya çıkar. $\mathrm{Bu}$ süreçte kaşıntı şikâyeti göreceli olarak azalır. Genellikle 18. saatten itibaren veziküller giderek büyüyerek bül halini alırlar. $\mathrm{Bu}$ dönüşüm sırasında ağrı şikâyeti mevcut değildir. Büller üçüncü günden itibaren belirgin hale gelirler (7). Bül oluşumuna; özellikle deri dokusundaki bazal hücrelerinin etkilenmesi sonucu epidermisin dermisten ayrılması neden olur (4). Büllerin sınırında çoğunluk ile "Nikolsky belirtisi" müspettir (15). Büllerin içinde kehribar renkli ve kıvamlı steril bir sıvı birikir. Bül oluşumu eklemlere yakın ise, eklem hareketlerinde ağr1 ve kısitlılığa neden olabilir (9). HG'na maruz kalan bir hastada 48. saatte izlenen tipik eritemli bölgeler ve bu lezyona eşlik eden çok sayıda bül Şekil-2'de sunulmuştur. HG temasına bağlı cilt lezyonları daha çok koltukaltı ve kasıklar gibi cildin nispeten ince olduğu, sıcak ve nemli alanlarda izlenir (6).

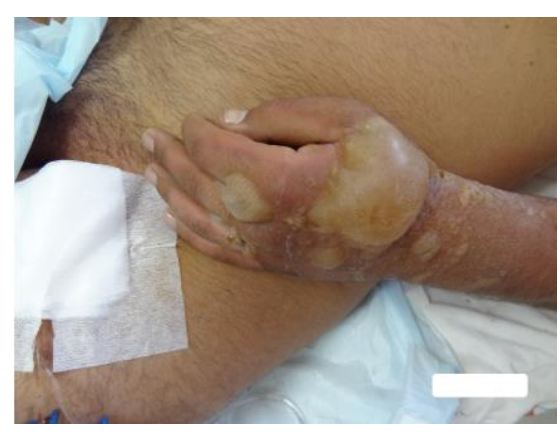

Şekil 2. Hardal gazı maruziyetinden sonraki 48. saatte ortaya çıkan tipik cilt bulguları (yaygın eritem ve çok sayıda büllöz lezyon) 
Epidermisin doku kaybına bağlı olarak gelișen derin yanıklar ise daha çok epidermisin inceldiği penis ve skrotum gibi anatomik bölgelerde izlenir (9). Geniş büller çoğunlukla kendiliğinden rüptüre olarak geniş cilt erezyonlarına, tam kat cilt kayıplarına, ülserasyonlara ve sekonder enfeksiyonlara neden olurlar (5). Bül halini almayan eritemli alanlar 10 ila 15 gün içerisinde hiperpigmentasyona uğrarlar. Bu bölgedelerde herhangi bir başka cilt lezyonu izlenmez. Rüptüre olan büller 4 ila 6 . günden itibaren skar dokusu oluşturarak 2 ila 3 hafta içerisinde iyileșirler. İyileșen alanlar pigmentlerini kaybettiği için bu alanın merkezinde hipopigmente, çevresinde ise hiperpigmente alanlar izlenir $(7,15)$.
Hastaların 15. günde yapılan fizik muayenelerinde; birinci, ikinci ve dördüncü hastanın vücut yüzeylerinin \%15-20'sinin, üçüncü hastanın ise vücut yüzeyinin $\% 35$ 'nin birinci ve ikinci derece yanıktan etkilendiği tespit edilmiştir. Hastaların vücutlarının etkilenen yüzeylerinde eritemli bölgeler, iyileşmekte olan skar dokuları ile çeşitli büyüklüklerde hipopigmente ve hiperpigmente alanlar izlenmiştir (Şekil 3 ve 4). Etkilenen bölgelerde görülen hipo ve hiperpigmente alanlar HG maruziyeti için patognomonik bir bulgudur. Hastalarda; göreceli olarak vücudun diğer bölgelerinden daha nemli olan batın ve koltukaltı bölgelerinde hiperpigmente alanlar daha sik izlenmiştir (Şekil 5 ve 6).

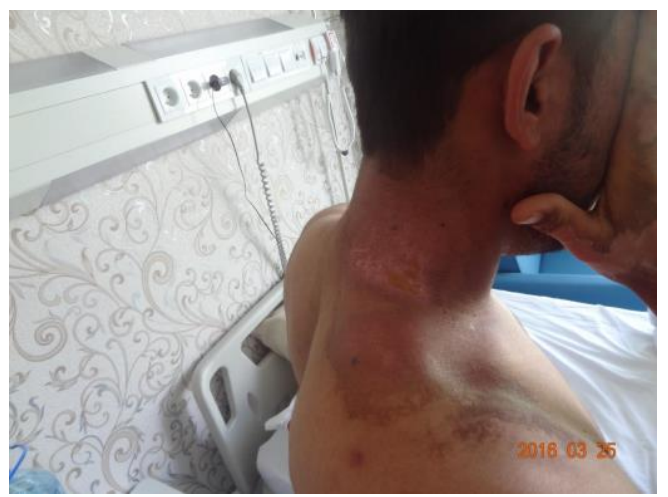

Şekil 3. Hardal gazı maruziyetinden sonraki 15. günde ense, sağ omuz ve sağ elde izlenen tipik hipo ve hiperpigmente alanlar ile eritemli skar dokular1.

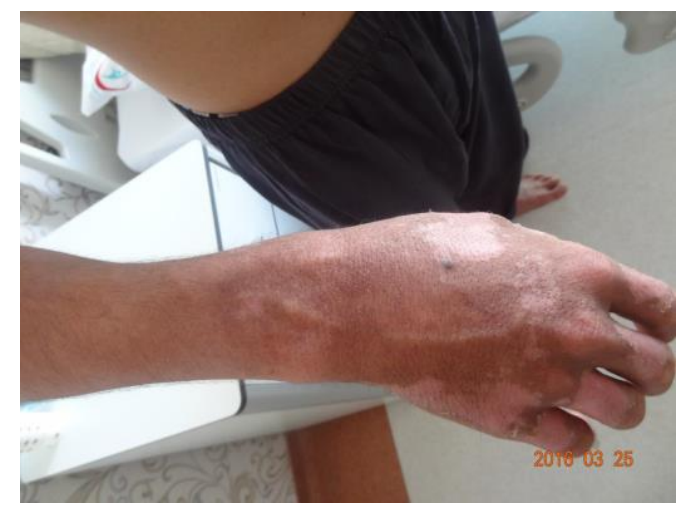

Şekil 4. Hardal gazı maruziyetinden sonraki 15. günde sağ elde izlenen tipik hipo ve hiperpigmente alanlar ile eritemli skar dokuları 


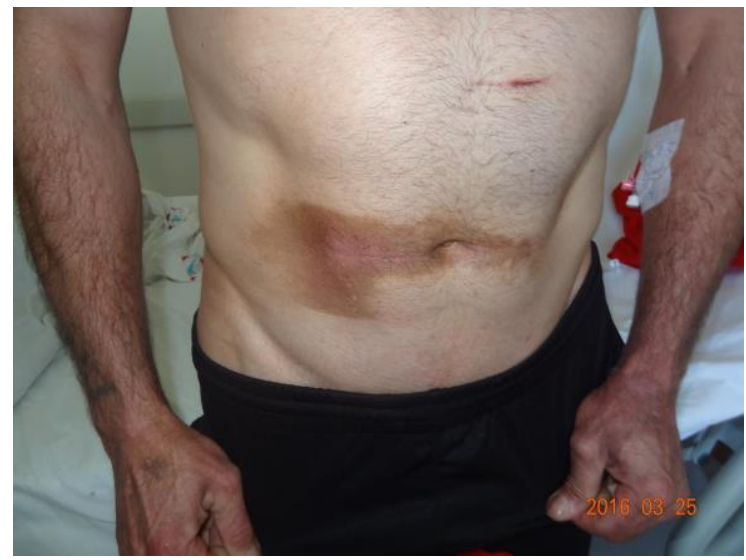

Şekil 5. Hardal gazı maruziyetinden sonraki 15. günde karın bölgesinde ve her iki elde izlenen tipik hipo ve hiperpigmente alanlar ile eritemli skar dokuları

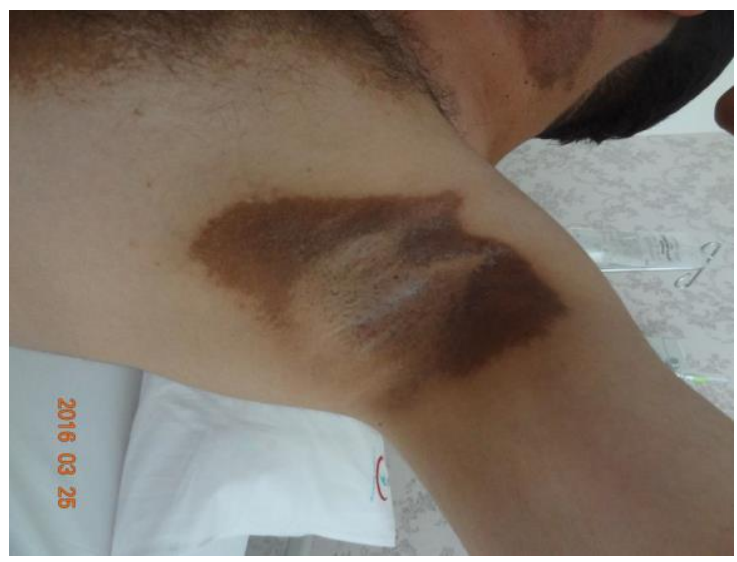

Şekil 6. Hardal gazı maruziyetinden sonraki 15. günde sol toraks, sol koltukaltı ve sol boyun karın bölgesinde izlenen tipik hipo ve hiperpigmente alanlar ile eritemli skar dokuları

Bulant1 ve kusma HG maruziyetinde meydana gelen sistemik intoksikasyonun bir sonucudur (14). Her dört hastada zaman zaman izlenen bulantı şikâyetlerinden dolayı antiemetik tedavi uygulanmıştır.

HG’na maruz kalan hastalarda ilk birkaç gün lökositoz izlenir. Üçüncü veya dördüncü günden sonra lökosit sayısı düşmeye başlar ve genellikle dokuzuncu günde en düşük seviyeye ulaşır. Ciddi lökopeni $(<200 / \mathrm{mL})$ hasta için kötü prognozun bir belirtisidir (5). Her dört hastanın maruziyet sonrası 15 . günde alınan kan örneklerinden çalışılan tam kan ve rutin biyokimya testlerinde herhangi bir patolojik bulguya rastlanmamıştır.

HG'na maruziyetin tanısını koymak için detaylı bir tıbbi hikâye ile tipik belirti ve bulguların tespit edildiği fizik muayene çoğu zaman yeterli olmaktadır. Ancak retrospektif HG maruziyetini biyoanalitik yöntemleri ile doğrulamak hem adli tıp açısından hem ayırıcı tanının doğrulanması açısından önem arz eder. HG'na maruz kalanlardan uygun koşullarda alınacak kan ve idrar örneklerinde başta beta liyaz metabolitleri olmak üzere DNA ve protein katım ürünlerini saptamak mümkündür (6).

HG'nın neden olduğu lezyonların tedavisine yönelik özel bir antidot bulunmaz. $\mathrm{Bu}$ hastaların tıbbi yönetiminde semptomatik bir tedavi yaklaşımı uygulanır (6). Lezyonların şiddetine ve hastanın genel durumuna göre uygulanacak tedaviler farklılıklar gösterebilir (9). Bununla birlikte; HG'na maruz kalan hastaların tedavisinde semptomların şiddetini 
azaltmak, yerel veya sistemik ikincil enfeksiyonları önlemek, yara/yanık bakımını sağlamak ve yara/yanık iyileşmesini artırmak, sıv1 ve elektrolit desteği sağlamak, beslenmeyi takip ve kontrol etmek, gerekli hallerde solunum desteği sağlamak hedeflenmelidir $(11,12)$. Göz, solunum sistemi ve cilt tutulumunun ikincil enfeksiyonlara neden olabileceği durumlarda HG'na maruz kalan hastaların yanık merkezlerinde veya yoğun bakım ünitelerinde takip edilmelerinin uygun olacağı değerlendirilmektedir.

HG'na maruz kalan yaralılarda; az görülen akut bir komplikasyon olan kemik iliği baskılanması haricinde ölüm nadiren görülür (14). Kalıcı görme kaybı olan vakalar hariç göz lezyonları 14 ila 21 gün içerisinde iyileşir. Yüzeyel cilt lezyonları da aynı sürelerde iyileşmekle beraber derin cilt lezyonlarının iyileşmesi iki ay kadar sürebilir. Üst solunum yolu lezyonlarında iyileșme için kesin bir süre vermek mümkün değildir (9). Klinik bulguları gerileyen ve cilt lezyonları iyileşen dört hasta; maruziyetten sonraki 25 . günde, hastanedeki tedavinin ise 11. gününde taburcu edilmişlerdir.

Bu çalıșmamızda; kimyasal terörist bir saldırı sonucunda hardal gazına maruz kalan dört hastanın tıbbi yönetimini belgelendirdik, bu kapsamda hastaların tanı ve tedavi süreçlerini inceledik. Alanındaki ulusal yayınlarda, bugüne kadar böylesi bir konu ele alınmadığ1 için, çalışmamızın olası bir hardal gazı saldırısı sonrasında yaralılara sağlık bakım hizmeti sunacak sağlık profesyonellerine rehberlik edeceğini düşünüyoruz.

Önemli bir afet potansiyeli olan kimyasal silahlar ile düzenlenebilecek terörist bir saldırının modern toplumlar üzerindeki korkutucu ve tahrip edici etkilerini öngörmek mümkün değildir. Böylesi terörist bir saldırı sonrasında, kurbanların olay yerine en yakın sağlık tesisine başvurmaları ve bu kişilere ilk müdahale edenlerin sağlık çalışanları olması kesindir. Bu kapsamda, kimyasal yaralıların tıbbi yönetiminde bilgi, kritik altyap1, planlama ve personel anlaminda hazırlıklı olmak her sağlık tesisi için mutlak bir zorunluluktur.

\section{Teşekkür}

Sağllk Bilimleri Üniversitesi Tıbbi KBRN Ana Bilim Dalı Başkanlığından Dr. R. Koray Eyison'a bu çalışmanın saha verilerinin hazırlanmasında verdiği emekler için teşekkür ederiz.

\section{KAYNAKLAR}

1. Ortatatlı M, Sezigen S, Ayan HA, Balandız H Kenar L. Terörizm kapsamında kimyasal, biyolojik, nükleer ve radyasyona bağlı yaralanmaların değerlendirilmesi. Turkiye Klinikleri $J$ Foren Med-Special Topics. 2015;1:44-52.

2. Kehe K, Szinicz L. Medical aspects of sulphur mustard poisoning. Toxicology. 2005;214:198209.

3. Romano JA, Lukey BJ, Salem H. Chemical warfare agents: chemistry, pharmacology, toxicology, and therapeutics, 2th ed, Taylor\&Francis;2007.

4. Sezigen S, Karayılanoğu T. Kimyasal savaş ajanlarının solunum sistemine etkileri ve tedavi yaklaşımları. Türk Hij Den Biyol Derg. 2006;63:129-34.

5. Balali-Mood M, Hefazi M. The pharmacology, toxicology, and medical treatment of sulphur mustard poisoning. Fundamental \& Clinical Pharmacology. 2005;19:297-315.
6. Thiermann H, Worek F, Kehe K. Limitations and challenges in treatment of acute chemical warfare agent poisoning. Chemico-biological interactions. 2013;206:435-43.

7. Mood MB, Abdollahi M. Basic and clinical toxicology of mustard compounds. Springer;2015.

8. Steinritz D, Striepling E, Rudolf KD, Schröder-Kraft C, Püschel K, HullardPulstinger A, et al. Medical documentation, bioanalytical evidence of an accidental human exposure to sulfur mustard and general therapy recommendations. Toxicol Lett. 2016;244:11220

9. Mood BM, Mathews R, Pita R, Rice P, Romano J., Theirman H, Willems J. Practical guide for medical management of chemical warfare casualties. Organisation for the Prohibition of Chemical Weapons, International Cooperation and Assistance 
Division, Assistance and Protection Branch; 2016.

10. Schmidt A, Steinritz D, Rudolfd KD, Thiermann H, Strieplingd E. Accidental sulfur mustard exposure: a case report. Toxicology Letters. 2018;293:62-66.

11. Kilic E, Ortatatli M, Sezigen S, Eyison RK, Kenar L. Acute intensive care unit management of mustard gas victims: the Turkish experience. Cutaneous and ocular toxicology. 2018;37:332-7.

12. Sezigen S, Ivelik K, Ortatatli M, Alamacioglu M, Demirkasimoglu M, Eyison RK, et al. Victims of chemical terrorism, a family of four who were exposed to sulfur mustard. Toxicol Lett. 2018;303:9-15.

13. AA [Internet]. Iraqi Turkmen mustard gas victims in Turkish hospital [cited 2019 Feb 01]. Available from https://www.aa.com.tr/en/middle-east/iraqiturkmen-mustard-gas-victims-in-turkishhospital/627685

14. Goverman J, Montecino R, Ibrahim A, Sarhane KA, Tompkins RG, Fagan SP. Sulfur mustard gas exposure: case report and review of the literature. Ann Burns Fire Disasters. 2014;27:146-50.

15. Kehe K, Thiermann H, Balszuweit F, eyer F, Steinritz D, Zilker T. Acute effects of sulfur mustard injury-Munich experiences. Toxicology. 2009; 263: 3-8. 